\title{
Thresholds of Change in Children's Literature: The Symbol of the Mirror
}

\author{
Sergio Arlandis ${ }^{1 *}$ (D), Agustín Reyes-Torres ${ }^{2}$ (D) \\ 1Department of Language and Literature Education, Universitat de València, Spain \{Sergio.Arlandis@uv.es\} \\ ²Department of Language and Literature Education, Universitat de València, Spain \{Agustin.Reyes@uv.es\} \\ Received on 24 January 2018; revised on 02 February 2018; accepted on 09 February 2018; published on 15 July 2018
}

\begin{abstract}
This article approaches the study of children's literature as a threshold of change that allows readers to explore the reality around them, imagine other worlds and understand other perspectives. Based on the notion of the child's cognitive development organized into four stages - pre-reading, fantastic stage, fantastic-realistic stage and aesthetics stage - reading becomes a resource to combine fantasy and experience where the mirror is a highly suggestive element and prone to hundreds of interpretations and applications as can be seen in the plots of well-known books such as the brother Grimm's Snow White, Lewis Carroll's Through the Looking-Glass, Michael Ende's The Neverending story and J.K. Rowling's The Philosopher's Stone, among others. As a result, as young readers go from one stage to another, the mirror gains greater symbolic complexity and they face the discovery of the self and the other as well as the confrontation between the so-called primary and secondary worlds, reality and the marvelous.
\end{abstract}

KEYWORDS: THRESHOLD, CHANGE, READING, FANTASY, MIRROR

\section{INTRODUCTION}

It is well known that the root of a significant part of child and young adult literature is popular folklore. However, folktales (themes, characters, adventures, moral lessons, etc.) were not originally intended for children. In fact, many of them had to be amended to eliminate the high component of violence, cruelty and arrogance that characterized them and that was part of the regular pedagogy of fear of their time. Such adaptations, which undoubtedly sharpened the didactic moral background of current folk storytelling, were carried out in a variety of ways: the replacement of punishment for other more suitable solutions, the permutation of certain characters and their personality traits (especially the scariest ones) and, finally, the change of some stereotyping features. As Colomer (1999) comments, these modifications are relevant because folktales denote images, symbols and myths that human beings have used in the past and still continue to use as patterns to understand the world and the relationships among people. In this way, it is also important to highlight the portrayal of "thresholds of change" included in folktales through which the main characters (children or not) face both the real and the imaginary world, producing thus a moral, contrastive and comparative reading between the two worlds, with its limitations and possibilities (Connell, 2000, p. 29).

Interestingly, the thresholds of change begin to appear when children's level of literacy, reading habits and literary competence allow them to individualize and construct their own interpretations. It is a concrete formative stage of personal indecision in the child that leads him or her to analyze their inner world, think critically, enjoy books and, eventually, acknowledge their value. Therefore, as Sipe (2008, p. 246) indicates, good children's literature should be characterized by offering its readers the "ability to impose a new narrative construction on the social facts at our disposal". Reading thus becomes a means to envision other realities and facilitate the construction of new meanings, not just a mere repetition.

Regarding the levels of language acquisition and young readers' cognitive development, this can be classified into four stages: pre-reading stage, fantastic stage, fantastic-realistic stage and aesthetic stage (Kucer, 2009). These phases would range from four years old in the first level until fifteen-sixteen years in the last. Here we will refer above all to the "fantastic stage" that sometimes, depending on the developmental stages of the reading competence of the child, will border or run alongside the phase "fantastic-realistic".

The truth is that the imprecision in defining certain boundaries between children's and young adult literature gives rise to the speculation of the processes of development of literary and cognitive competence among children (Cuetos, 2005, pp. 43-44). In the face of such uncertainty, some texts are caught up in those cycles of transition: this is precisely where folktales often fit well since they accompany children in their progress towards a stage

*To whom correspondence should be addressed:

Departamento de Didáctica de la Lengua y la Literatura

Facultat de Magisteri, Universitat de València

Avenida de Tarongers, 4

46022 Valencia 
of maturity. Folktales, therefore, become portals through which children begin an intense and fascinating rite of reading and personal initiation. Consequently, the emergence of the thresholds of transformation coincides precisely with that formative-decisive step of the child, between six and eight years old, which is also the passage from the cycle of Infant Education to Primary Education. At that point, stories emerge and become a significant resource that can be used in the classroom to work on children's literary competence, and more particularly, on the aesthetic reading, that fun and engaging interaction that popular folk tales can trigger. This is a key element that provides students with a pleasant experience in which learning becomes meaningful because it is the reader who builds the ideas and constructs the knowledge becoming thus a critical thinker (Reyes-Torres 2014, pp. 42-43).

Actually, in these narratives that, as we have noted, are framed on the frontier of young readers' evolution, we find that it is not only the development of the character that the child witnesses, but also about children themselves becoming aware of their own process of maturation. As Díaz Armas (2006, p. 80) puts it, readers culminate the adventure of reading with a "greater physical strength and robustness". In this way, the child-reader experiences an integral transformation, like a mirror-reflectioneffect type (hence the recurrence we are going to analyze here), through which he recognizes himself in the reading of others who, like him, have begun an introductory journey towards the construction of their own identity. As is the case of the characters, the child must also face the risks that this transformation entails: not being able to discern, exactly, the border crossing, that is, the threshold.

While at this stage the child already knows the basic structure of narratives (beginning, conflict, climax, resolution) and can also differentiate the portrayal of alternative or complementary realities, the natural educational value of these narratives lies precisely in the fact that, despite their dose of imagination, they respond to the young reader's ultimate and intimate needs (Casanueva 2003). The child seeks to explain his own existential and vital step towards a more complex structure of his daily experience, introducing complex concepts such as responsibility, behavior, emotional restraint, solidarity, etc (Gargallo, 2000, p. 69-75). In this respect, although there are certain traditional patterns to which we will refer in the present work, the way of combining and developing these concepts is extremely varied. The existence of highly transformative frontier passages between worlds and characters is, without a doubt, one of the greatest and most effective educational and creative resources of all children's and young adult literature (Martos Núñez, 2011, p. 6-7).

We do not intend to stop here by any means to discuss of the internal division, features and delimitations that characterize this type of literature, but we do need to determine what we understand as such (Vieiro, Gómez, 2004, p. 63-65). This will serve as a general frame for our starting point to build up our argument on how the mirror is a highly recurring symbol as a threshold for transformation of the young protagonists and the reality that surrounds them.

\section{LITERATURE REVIEW}

\subsection{Main features of children's and young adult literature}

One of the first elements to be taken into account is that the literary works addressed to children sometimes result in being overtly didactic and moralizing (Hunt 2001), disregarding perhaps the tastes of their young potential audience, among whom the didactic interest could be considered a sonorous absence within their most outstanding interests. Based on the theories of Petrini (1958), Antonio Moreno (1998) establishes a series of general guidelines that any book for children should have: first, considering the reader's point of view, stories should be fun, exciting and captivating. Likewise, however fictional the stories might be or seem, they should be imaginable and credible within logic (Nikolajeva, 2010, p. 146). Secondly, from the point of view of the educator, they have to be true in any dimension of space and time in which the work is situated (whether it is a magical world, timeless, future, past or present). At the same time, they must be morally valid and with a psychological serenity that would leave some room for passion, but not making this the main argument of the story itself. Lastly, from the point of view of the writer, the literary work must have clarity of exposition, with a language that is not inferior to the standard and that takes into account the ages of the readers. Also, whenever possible, the writing should be accompanied by complementary illustrations. To conclude, we do not think that to gather these characteristics gives us as an automatic result, excellent work for children or young adults (Wyse, Andrews, \& Hoffman, 2010). Nevertheless, it can be considered a good starting point for determining what children and adolescents should read and with what writing style their texts must be woven (Beck, 1998, pp. 11-31).

So if, in a certain way, the aim of children's and young adult literature is to accompany and reflect that transformation of the young reader, it is not surprising that the symbol of the mirror (and other analogies such as water or the moon) has a certain presence and continuity in its most emblematic texts. As a matter of fact, the mirror constitutes one of the most recurring thresholds of transformation also in universal literature. That is why its emblematic value in this type of stories is unquestionable.

\subsection{From the fantastic to the marvelous}

There are many theories that have tried to determine the origins of this so-called literature for children that has found so much potential in adventure and in the marvelous as models of transformation. Certainly, as many authors such as Vladimir Propp, Mélétinski, Bremond, Lévi-Strauss or Marisa Bortolussi, among others, have asserted, folklore, fairy tales and much of the oral popular literature have undoubtedly been fundamental and foundational axes of what we now refer to as children's and young adult literature, and on the film too (Vogler, 1992, pp. 22-40). Today such literature has clearly evolved from its origins and we can highlight the fantastic adventure type as a generic hybrid that outweighs all the others. This might be because it brings together the opportunity to experience both the marvelous side of the fantasy and the adventures of exploring the universe (SánchezEscalonilla, 2009), that is, wonder and exploration.

We cannot forget, however, that with Alice in Wonderland (1865) and Through the Looking-Glass (1871), Lewis Carroll had already anticipated much of the parameters of this merger that Barrie eventually would define and single out for the younger audience. Accordingly, we can note that it was in the first half of the twentieth century when the fantasy-adventure form became more directly identified with children's literature. Likewise, it would be decades later when Todorov (1973) would write his classifications of the fantastic and the marvelous whose theories stemmed from the reader's emotional responses rather than the nature of the story. Here we will quote them only succinctly, leaving the door open to future works that theoretically delve in that direction: the pure uncanny, the pure marvelous, the fantastic-uncanny and the fantastic-marvelous. It is in this last variant that we mainly find 
the presence of the mirror as a magical threshold, since through its mediation we go from the fantastic to the marvelous with an acceptance of the magical as the sole and exclusive version of the facts. In this regard, we must also remember that in many mythological accounts the physical thresholds were already considered as access to a superhuman world where heroes lived unusual and wonderful experiences, as for example, the Pillars of Hercules, a symbol of the last boundary for the old Mediterranean sailors.

To continue, other theoretical-reflexive texts by authors such as Michael Ende himself, Nikolajeva, Sable Jack, Umberto Eco, etc., allow us to conclude that the fantastic is a peculiar diegetic universe where the natural laws are transgressed and where the characters have the opportunity to contemplate or at least perceive the mysteries related to their own existence (Sánchez-Escalonilla, 2009). To that we should add the definition of Richards Matthews (2002) for whom this type of fiction evokes the marvelous, the mystery or the magic: it ignites an intuition of the possibility that exists beyond the ordinary, material and rationally predictable world in which we live. In the same way, the marvelous can be understood as that essence of fantasy, which alludes to those worlds, supernatural beings and objects beyond the ordinary world; likewise, they are also linked to a quality of surprise and amazement, where magic and the impossible would reside along with the inexplicable, and where the natural laws would be altered, especially those that affected time and space, as theoretically proposed by Maria Nikolajeva (1988) and Sable Jack (2004). Let us, then, proceed to explore how the fantastic and the marvelous are portrayed in children's and young adult literature.

\subsection{The encounter between the Primary world and the Secondary World}

It was J.R.R. Tolkien, in his paradigmatic essay entitled "On FairyStories" (1994), who, when differentiating the marvelous, the adventure and the fantasy as a whole, established the opposition on a theoretical level between the dimension of the ordinary (shared by the reader, protagonist and author) and the dimension of the fantastic, (shared by creatures, in this case, fairies). The first one was called the Primary World and the second one the Secondary World or the "Distant kingdom", as Propp, called it in his book The Historical Roots of Fairy-tales (1997). Obviously, from the relationship that was established between these two worlds, the concept of journey, linked to adventure and to formative and moralizing aspects, came up implicitly. As Teresa Colomer (1999, p. 16) comments, the educational asset of literature lies precisely in the fact that it offers the possibility of establishing a different view of the world, of asking oneself about the human condition taking as a reference the creation of possible worlds (p. 16).

In this way, the reaction of surprise and amazement upon experiencing the marvelous is given when a human person or a humanized creature crosses the limits of fantasy, provoking an encounter between two worlds. While there is a place for the marvelous among them, it is necessary to observe that together they must still form a possible world, since the faith of the reader does not come from an attitude to the story but from the truth plus the plausibility suggested by the narrative itself. Without that initial astonishment (which is the result of the unexpected confrontation), there would not be a fantasy story, so there must be a progressive internal and external transformation in the protagonist as well as a transgression of the delimitation of the two worlds. Here is where the mirror, as a threshold, is to have one of its oldest and recurrent meanings in literature. This is because it provokes a collision of experiences, for example, the usual versus the unusual, which, in addition to introducing fantasy into history, endows the genre with its peculiarly mysterious appeal. Thus, as Selma Lanes (1972, p. 93) would comment at the time: the term fantasy was reserved for those tales where magical kingdoms could exist, but in which the characters had to find the means to move to them. Therefore, fantasy was necessary as a nexus that connects reality and desire.

As Maria Nikolajeva (1988) would point out, there are up to three modes of establishing a connection between these two worlds: on the one hand, the open mode, that is, that one in which both coexist since they are connected through a magic threshold. Here the ordinary realm is strongly influenced by the return of the protagonist once the adventure has been carried out in the extraordinary context (temporal and/or spatial). On the other hand, the closed mode, in which the protagonist would face the adventure within an ordinary world that has nothing to do with the daily life of the reader and in which the magic element would come through the mediation of magicians or witches. These controversial figures would find themselves in a constant conflict between good and evil, a dichotomy that is somehow necessary in the first cognitive schemas of the human being who is often inclined to believe in the existence of binary schemes. Finally, there is the involved mode, in which the secondary world does not appear in the story and is never visited, but interferes or meddles in the primary world through objects or magical characters.

\section{DISCUSSION. THE SYMBOL OF THE MIRROR}

As will be shown, the symbol of the mirror is highly suggestive and prone to hundreds of interpretations and applications. As it can be expected, its symbolism becomes even more complex in children's and young adult literature as we go from one stage to another. Thus, in the pre-reading stage (four to six years old), it hardly serves as anything more than an object that only reflects the self in its daily routine: washing the face and teeth, combing and recognizing oneself. In this stage the mirror is devoid of magic and illustrations dominate the stories almost in their totality. Furthermore, since it is a stage in which the temporal consciousness has not yet been developed properly and the self is in a phase of auto-discovery as a subject, the mirror does not take us to any unexplored place (secondary world) because the focus is on the body itself as a world, without entering in any kind of introspection. At this age, it is the child's eye that transforms objects and not the other way around. The mirror does not open as a threshold or trigger any mystery regarding our own reflection. Likewise, it does not represent any danger or a threat that can trap our soul because simply there is no awareness of it. Finally, there are also no cursed characters such as vampires or demons that are unable to see their image reflected.

This does not happen, however, in the so-called fantastic stage, from six to eight years old, in which an interest for the marvelous awakens in the child who finds himself in a personal transition towards logical thinking. As noted by Gómez del Manzano (1987), as children begin to read they take a first step towards "intellectual realism" which in turn leads them to magic. Thus, in this stage, the mirror continues to maintain its primary function of reflecting the self but also reveals a fantastic complicity. For example, in the saga The Little Vampire (2005) by the German author Angela Sommer-Bodenburg (2005), Anton, a human child, and Rüdiger, a young vampire (see that these types of characters already enter at this stage) establish a relationship of friendship with parallel visits to their respective worlds. But, as we read we learn that Rüdiger, among other things, cannot see his reflection 
in the mirror. Although this does not happen under the dramatic tension of lacking a soul, he serves as an example of a young person who has a series of qualities that in the primary world are extraordinary, but also limited. Consequently, the confrontation of worlds lies in the possibility/impossibility of adapting to the means of each reality as well as in the possibilities of adaptation of each character.

As we can see here, the child is already aware of the notions of difference, difficulty and effort, but also of what risk and danger mean. In this case, Anton and Rüdiger have begun a journey of learning and friendship. Perhaps because Rüdiger can not have a reflection, Anton does not crave being a vampire. However, he still accepts him as he is. In this way, the reality represented in the text is not only magical but also different and one must know how to face those issues within the adventure. The crossing of the thresholds of transformation brings along therefore a formative awareness: readers will return more prepared from their adventures, since the risk is not connected at this age with the idea of dying as a final ending, but with the failure of returning without success from the experience.

Within this phase of the child's development, we could also include the story or adaptation of Snow White written by the Brothers Grimm. Here, as we all know, the mirror is not a threshold, but an oracle that, strange as it may seem, can speak. However, no one is surprised about it in the secondary world. This might be because it is an object turned into a subject whose influence is central in the subsequent transformation and evolution of the character. In fact, in Snow White we might have the first great evidence of the mirror not only as a flat screen reproducing the images, but also as one that can also contain and absorb them (Cirlot 2008). This magical endowment makes the mirror a direct participant in the plot of the story and even responsible for the transformation of it, since as we can see, mirrors at the fantastic stage are not represented as simple neutral objects from which one just obtains objective information. By contrast, they actively serve as agents of disorientation. As Jean Chevalier and Alain Gheerbrant (1997) remind us, the origin of this could be in the image of the Great Mirror of Wisdom in Tibetan Buddhism that was able to show the most sordid reality that exists behind the transitory appearance. That is why the mirror can not lie to the queen about the beauty of the young princess, but neither about her danger or threat. In this sense, he shows the inconsistency of human obsessions, those that deform reality as a result of our interests and selfishness. Moreover, in the traditional folklore, which served as the basis for the Grimm Brothers' story, a mirror was more spectral and not so reflective. It even had a translucent form that when it was called it appeared from the shadows. However, in its infantile adaptation, much more affable, the mirror is summoned with the magic of the words "mirror, mirror on the wall" or "Magic mirror on the wall". Then, as we know, from the background a neutral, humanized face would appear. Is it a manifestation of the world of the non-living? Is it the world of souls where truth leaves no room for lies and the human being faces his true reality? Somehow the child sees that there are mysteries that we do not understand and that often influence our actions. Some people refer to it as destiny and that is, after all, the goal of the adventure: to find and fulfill our fate.

Similarly, we find a comparable case in the Odyssey, where Ulysses fights against his own destiny, one that is marked by the gods. Here the journey, the transformation and the crossing of the threshold constitute a great metaphor of the processes of formation of the human being towards his maturity. Let us remember that Ulysses fights against the imposition of a series of limitations, desires and conditions which transmute the self in an external and internal way. Something similar happens to some young characters in children's literature that are defined by their exploratory eagerness, their predisposition for adventure and their desire to search for the marvelous. However, all this ceases when the child's sense of contemplation yields to the pragmatic desire of possessing the primary world. At this point, we could say that that magic is in danger of disappearing and, with it, the possibility of crossing the threshold again.

Thus, at this stage of the child, a symbolic excision begins to be emphasized, one that will gradually acquire more form and determination. It is the existence of the primary world versus the secondary world: the interference between them can generate chaos and disorder or, on the contrary, a new vision of reality where there is a place for failure, contradiction and nonsense. This is where we can also refer to the best example of this nonsense: Lewis Carroll' Alice through the Looking Glass. This book combines the journey to the other side with the reverse of reality in all its complexity. We must remember that six months after her initial adventure in "Wonderland" Alice has a dream in the always symbolic autumn season: now it is no longer about falling through the tunnel, but about the crossing of a threshold. This crossing generates expectations in the young protagonist who is eager to learn about the complexity and the anomaly of what is reflected. In the end, it seems to tell us that depending on how one imagines or looks at the reality that surrounds us this one can adopt a more or less wonderful or changing aspect. Similarly, it hints that fantasy takes on a very active transforming role because every thought, every step or every movement carries its reverse and its consequence, as it curiously also happens in chess, a game on which the story and the adventure of Alice is based in this novel.

In Carroll's story, it is the young woman who is the strange element in that reality of the reverse and it is also her who must conform to the new rules that govern it. Could we say that the reality portrayed is in fact the one we face after we leave childhood and its ideal models behind? It is interesting that Alice Lidell, the girl to whom Carroll dedicated her books, was already twenty years old by then and that meant a drastic change in her duties as a woman of the time. What is more, Carroll would go beyond and question: what if there was an inverse logic beyond our own self-absorption? Umberto Eco in his work Over the Mirrors and Others Essays (2012) states that the mirror:

reflects the right exactly where the right is and the left where the left is. It is the observer (naive even when he acts as a physicist) who, through self-absorption, imagines himself to be the man in the mirror, and when he sees himself, he notices for example that he is wearing the watch on his right wrist. But the fact is that he would wear it if he, the observer, is who is inside the mirror. However, whoever avoids behaving like Alice and does not penetrate the mirror, does not suffer this illusion. (p. 15)

Let us not forget that the need to know and to experience leads the human being to abandon his home and to enter into the existential adventure, both in a metaphorical and real way. Through it, the child (in its progressive formative step) seeks parallel worlds, exact to the model that he leaves and among which it is also his own self, one that he will need to complete by recognizing himself in the other, that is, through a process of empathy with other human beings. In this line of discussion, there 
is a superstitious belief rooted in popular tradition that if a mirror breaks, there are seven years of misfortune, and this number is a symbolic reference to a fulfilled temporal cycle in life. At that point, it is not possible to go back, the symbolic door to return is broken:

Somehow, it is this same curiosity and risky initiative that leads Alice to state:

There's the room you can see through the glass -that's just the same as our drawing-room, only the things go the other way... [...]

'How would you like to live in Looking-glass House, Kitty? [...] Let's pretend there's a way of getting through into it, somehow. Let's pretend the glass has got all soft like gauze, so that we can get through. Why, it's turning into a sort of mist now, I declare! It'll be easy enough to get through_-'She was up on the chimney-piece while she said this, though she hardly knew how she had got there. And certainly the glass was beginning to melt away, just like a bright silvery mist.

In another moment Alice was through the glass, and had jumped lightly down into the Looking-glass room. [...] 'Because there'll be no one here to scold me away from the fire. Oh, what fun it'll be, when they see me through the glass in here, and can't get at me!' (Through the Looking-Glass 2009: 127-128)

The fragment reveals much of the symbolic meaning of the mirror and its operative transformation: from the solid to the fluid state, from the objective to the subjective world, from the everyday routine to discovering of new spaces and characters, from dreaming to daydreaming, from childhood to adolescence. It demands a duality of form or, better still, its unfolding, just as literature itself allows fiction (that reverse of reality) to constantly legitimize itself, perhaps because literature has been the poetic precursor of those parallel and mysterious worlds characterized by the existential enigma of the unfolding, with their recognitions, their strangeness, their phantasmagoria, and so on. It is not surprising then, that the mirror also reflects the creative intelligence capable of transforming silence into words and creating new worlds, but the question is what kind of creation is it? In its image and likeness as proposed in the biblical passage of Genesis? If this were the case, fantasy, magic or the marvelous would be inside the self, but in its other side or dimension: the dream. Actually, this theme is prevalent in many authors such as Poe, Borges, Cortázar, Hoffmann, Unamuno, Machado, etc., and it is brought to children through the celebration of adventure itself as a creative and cognitive act, since it is after all an enlightening stage of their formation as human beings.

This formative phase, however, would occur in the third stage: that which we call fantastic-realistic (until the age of twelve), and where the primary and secondary worlds are going to clash. As Moreno (1998, p. 36) underlines this is also when the child demands answers to their questions and expects solutions to be logical and grounded in reality. But as they approach the threshold of adolescence, children's rationality enters in conflict with their desires and with their disturbing dreams or illusions, since these can be speculations (remember, mirror in Latin is speculum), perhaps reflections of a light that we do not see, hence it might have a dark and lunar nature. There can be thus a separation between body and soul. We see this, for example, in The Neverending Story (1979), by Michael Ende. Whenever Bastian wants to submerge himself in his secret adventure in the form of Atreyu (his literary alter ego that faces the darkness that is precisely taking over the Secondary World), he speaks before the mirror and summons both himself and his creativity: this very example is why the future of Fantasia depends on the belief and reading of children. Similarly, in the same novel, the young warrior must cross the Mirror Gate, which is shaped (not coincidentally) in the form of a half moon. This gate crosses the dark world and leads to Uluyaya, its final destination. A similar case occurs with Sarah in the film Labyrinth, directed by Jim Henson in 1986, who summons the goblins by making a spell before the mirror, in a somewhat unconscious way, as if she were following a ritual of convocation in the middle of the night. Finally, let us remember that urban legend based on the paranormal that says that when pronouncing the name of a girl in front of a mirror (there are many variations on this), she appears to snatch, precisely, your soul or, in a less frightening version, to grant you the desire that you wished for.

Harry Potter, in The Sorcerer's Stone (1998), meets the Erised mirror, whose first particularity is to have a name, unlike the number of anonymous mirrors that populate children's books. Strangely enough, before meeting the mirror, Ron, his inseparable friend, is teaching Harry, to play magic chess. Is this a simple coincidence considering its reversible and symmetrical arrangement on the board? We do not think so. Once the room where Erised is found, the young protagonist reads his inscription (which is upside down but says "I show not your face but your heart's desire"). The big surprise came fast when Harry looked at himself in the mirror: "For he had seen not only himself in the mirror, but a whole crowd of people standing right behind him" (1998, p. 208). Curiously, this occurred to a child who, until now, if something characterized him was loneliness. There arises, then, a fear of deceit or delirium, but soon after, Harry sees his parents close to him for the first time and along with them other relatives, undoubtedly recreating that moment that they say it happens when a person is dying and sees his loved ones around him. The mirror is, therefore, also a threshold on the side of life, but from another perspective. Master Dumbledore offers us a logical explanation when he says:

'It shows us nothing more or less than the deepest, most desperate desire of our hearts. You, who have never known your family, see them standing around you. Ronald Weasley, who has always been overshadowed by his brothers, sees himself standing alone, the best of all of them. However, this mirror will give us neither knowledge or truth. Men have wasted away before it, entranced by what they have seen, or been driven mad, not knowing if what it shows is real or even possible. [...]' (The Sorcerer's Stone, 1998: 213-214)

The mirror can not only take you to the world of fantasy and fun, but as Plato had already warned us, it can also trap you in some kind of illusion and absorb your life or lock your senses turning the experience into pain like in the case of Cecilia, the protagonist of the novel Through A Glass, Darkly (1993) by Jostein Gaarder. And this causes fear and restlessness in those who already know that existence itself is marked by instants, by experience, by excitement, but not by the limitless reverie that hinders our progressive inner transformation and does not enable us to progress as human beings. Could this kind of reading have a hidden didactic purpose? Maybe and if that is the case that would be the reason then why these types of stories are attractive for young readers. 
The mirror, indeed, can trap your soul, as it happens recurrently in horror films where the supernatural, through reflection, invade reality with its dark plan and its most spectral truth. But maybe it just happens because the adult contemplates himself as a journey without return or maybe just because he knows that behind this reflection there are many hidden and silenced undersides that can be revealed and could show then the true face of who we are (or will be) in real fact. In this way, it must not surprise us that in the folk tradition, which we pointed out as the origin of children's and young adult literature, we can find that in those homes where there is a death, the mirrors are covered with handkerchiefs and sheets for fear that their inert reflections remain in them. Moreover, we can also refer here to the curse of Narcissus as a symbolic and meaningful warning of the danger that certain appearances and attitudes may cause. The child, we can infer, must pursue a dream to make it real but not an illusion, a mirage or a figment that could drive him to find emptiness and desolation: such could be the educational reading of much of all folk literature adapted for the young readers.

\section{CONCLUSIONS}

Therefore, the symbol of the mirror has been varying its representation in children's literature depending on the formative stages and the cognitive development of children. This is especially noticeable in those stories where the structure of the fantastic adventure dominates the plot and is marked by the confrontation and complementation of the primary and the secondary worlds. In these cases, the mirror goes from being a mere decorative object that shows reality as the discovery of the self to having active participation that shapes, transforms and even questions reality. So it serves as the union of two worlds that come into contact through its changing surface but also, in some circumstances, through the use of some specific words that have the power to change the daily routine. Hence, mirror and word are associated in most of these books. Furthermore, it is the fear and the awareness of death as well as the existence of other values such as passion or frustration, for example, that endow the mirror itself with a more enigmatic, more surprising and mysterious character; sometimes, as we have seen, the mirror also turns into a dangerous and gloomy symbol, because if we need the light to be able to see ourselves in it, it is also true that it can lead us to the deepest of the shadows, where there is an even greater death than the physical one: that which consists of forgetting life as Dumbledore mentioned and as Carroll himself also reminds us when he asks us in his final chapter the lapidary "Which dreamed it?". Sometimes returning to the side of order is the most difficult step to take, for we no longer do it as we once did: we return with a new look that gives us the experience of having crossed the threshold of the mirror, the limits of language, that wonderful time that opens to a truth that gives us a deeper image of what we are or can be. Perhaps in the end it is true that a good book really is a mirror that calls us to read it, to open it, to cross to the other side so that it can take us out of our particular ordinary world to remind us how we looked at it for the first time and how we made it part of ourselves.

\section{REFERENCES}

Beck, I. L. (1998). Understanding Beginning Reading: A Journey Through Teaching and Research. In J. Osborn \& F. Lehr (Eds.), Literacy for all (pp 11-31). London/ New York: Te Guilford Press.

Carroll, L. (2009). Alice's Adventures in Wonderland and Through the Looking Glass. Oxford: Oxford University Press.

Casanueva, M. (2003). Relaciones entre Folklore y Literatura Infantil. Claves Interpretativas. Salamanca: Globalia Ediciones Anthema.
Chevalier, J. \& Gheerbrant, A. (1997). Dictionary of Symbols. London: Penguin Books.

Cirlot, J. E. (2008). Diccionario de símbolos. Madrid: Siruela.

Colomer, T. (1999). Introducción a la literatura infantil y juvenil. Madrid: Síntesis.

Connell, J. M (2000). Aesthetic Experiencies in the School Curriculum: Assessing the Value of Rosenblatt's Transactional Theory. Journal of Aesthetic Education, 34 (1), 27-35. doi:10.2307/3333652

Cuetos, F. (2005). Psicología de la lectura. Madrid: Cisspraxis.

Díaz Armas, J. (2006). Personajes de la literatura juvenil: cambio y maduración. In Personajes y temáticas en la Literatura Juvenil (PP. 73-98). Madrid: Aulas de Verano. Ministerio de Educación y Ciencia.

Eco, U. (2012). De los espejos y otros ensayos. Barcelona: Debolsillo.

Gargallo, B. (2000). Procedimientos. Estrategias de aprendizaje. Su naturaleza, enseñanza y evaluación. Valencia: Tirant lo Blanch.

Gómez del Manzano, M. (1987). El protagonista-niño en la literatura infantil del siglo XX: incidencias en el desarrollo de la personalidad del niño lector. Madrid: Narcea.

Hunt, P. (2001). Children's Literature. Oxford: Blackwell.

Jack, S. (2004). Writing the Fantasy Film. Heroes and Journeys in Alternate Realities. New York: Michael Wiese Productions, Studio City.

Kucer, S. B. (2009). Dimensions of Literacy. A Conceptual Base for Teaching Reading and Writing in School Settings. London/New York: Routledge.

Lanes, S. (1972). Down the Rabbit Hole. Adventures and Misadventures in the Realm of Children's Literature. New York: Atheneum.

Martos Núñez, E. (2011). Los entornos constructivistas de aprendizaje (ECA) y la educación literaria. Puertas a la lectura, 23, 4-13.

Matthews, R. (2002). Fantasy. The liberation of Imagination. Londres: Routledge.

Moreno, A. (1998). Literatura infantil. Introducción en su problemática, su historia y su didáctica. Cádiz: Universidad de Cádiz, Servicio de Publicaciones.

Nikolajeva, M. (1988). The Magic Code. The Use of Magical Patterns in Fantasy for Children. Estocolmo: Almquist \& Wiksell International. doi:10.1080/0305764X.2010.481258

Nikolajeva, M. (2010). Literacy, Competence and Meaning-making: A Human Sciences Approach. Cambridge Journal of Education, 40(2), 145-159.

Petrini, E. (1958). Estudio crítico de la literatura infantil. Madrid: Rialp.

Propp, V. (1997). The Historical Roots of Fairy-tales. Bellingham: Western Washington University.

Reyes-Torres, A. (2014). Literacy Education: The First Step towards Literary Competence. En A. Reyes-Torres, L. Villacañas \& B. Soler (Eds.), Thinking Through Children's Literature in the Classroom (pp. 42-52). Cambridge: Cambridge Scholar Publishing.

Rowling, J. K (1998). Harry Potter and the Sorcerer's Stone. New York: Scholastic Press.

Sánchez-Escalonilla, A. (2009). Fantasía de aventuras. Claves creativas en novela $y$ cine. Madrid: Ariel.

Sipe, L. R. (2008). Storytime: Young Children's Literary Understanding in the Classroom. New York: Routledge.

Sommer-Bodenburg, A. (2005). The Little Vampire. London: Andersen Press.

Todorov, T. (1973). The fantastic: A Structural Approach to a Literary Genre. New York: Cornell University Press.

Tolkien, J. R. R. (1994). Sobre los cuentos de hadas. In Árbol y Hoja (pp. 13-100). Barcelona: Minotauro.

Vieiro, P. \& Gómez, I. (2004). Psicología de la lectura. Madrid: Prentice Hall.

Vogler, Ch. (1992). The Writer's Journey. Mythic Structure for Storytellers and Screenwriters. Michael Wiese Productions: Studio City.

Wyse, D., Andrews, R. \& Hoffman J. (2010). The Routledge International Handbook of English, Language and Literacy Teaching. London/New York: Routledge.

How to cite this article: Arlandis, S., \& Reyes-Torres, A. (2018). Thresholds of Change in Children's Literature: The Symbol of the Mirror Perspectives. Journal of New Approaches in Educational Research, 7(2), 125-130. doi: 10.7821/naer.2018.7.275 